been recognized as one of the standard books on bacteriology and has been used widely, both by medical students and post-graduate workers. The present edition has been thoroughly revised and brought up to date. New knowledge and new methods of investigation have illustrations have been replaced by photomicrographs. The tenth maintains the high reputation of its predecessors and we have no doubt it will be as popular with medical students as the previous editions.

\section{L. P.}

\section{NOTES ON BACTERIOLOGY AND CLINICAL PATHOLOGY FOR NURSES.-By Herbert Rogers, M.D., C.B. (Bristol) 1938. H. K. Lewis and Company, Limited, London. Pp. vii plus 40. Price, 1s.}

THIs little book has been written to assist nurses preparing for the examinations required by the General Nursing Council and to create an interest in the pathological investigations carried out on their patients. The first half of the book consisting of 16 pages is devoted to the clasifia protozoa, and animal parasites, and the second half to clinical pathology and the methods of collection o pathological specimens. The author has succeeded remarkably well in giving a simple and a clear account of the nature of bacteria and other human parasites. a study of which will help the nurse to understand the meaning of the various laboratory investigations carried out on patients and will lead to an intelligent co-operation between the wards and the laboratory.

$$
\text { C. L. P. }
$$

AIDS To BACTERIOLOGY.-By W. Partridge, F.I.C. Revised by H. W. Scott Wilson, B.Sc., B.M., B.Ch. (Oxon.). Sixth Edition. 1938. Baillière, Tindall and Cox, London. Pp. vil. Plus 300 . Price, 5 s. THE sixth edition of this well-known member of the Aids Series has been thoroughly revised. The classification as recommended by the Society of American Bacteriologists in a slightly modified form and which has been generally accepted by the majority of English edition. This is a distinct advantage as it must lead to a unifhis is a distinct advantage as clearer understanding orm in in that in of different genera. It new nomenclature the abbreviations udoption or the genus Bacterium and the genutions used for the gendferentiated and in the abbreviated form stress is not laid on the great differences ated form

This book is of immense value to the student not only for revision purposes, but it will help him in the understanding of junction with of the subject when it is ans and with his lecture with one of the larger textly large amount of inform notes There is a remarkably large contributions to including the important resible form, which will bo bacteriology in a readily and also to the medical bacteriologist who desires to refresh his memory on any particular subject.

\section{I. P.}

A SYNOPSIS OF PHYSIOLOGY.-By A. Rendle SY OF PHIS, M.A., B.Sc., M.D., F.R.C.S., and C. L. G. 1938. John Wright, Illustrated. Price, 10s. 6d.

THIs small book is an admirable collection of up-todate information on physiology. The chapter on chemistry will be of great help to students. The subject-matter is of great hritten and not monotonous to read. It is a very suitable book for students for quick. It is a very suitable book for st will also quick revision before their examinations. It will also the subject. It is trusted that the book will meet an eager demand.

P. D,
THE AMERICAN ILLUSTRATED MEDICAL DICTIONARY.-By W. A. Newman Dorland, A.M., M.D. F.A.C.S., Lieut.-Col., M.R.C., U. S. Army. Eighteenth Edition. 1938. W. B. Saunders ComEighteenth Ediliphia and London. Pp. 1607. pallustrated. Price, 30s. (plain). 32s. 6d. with thumb index

IT is perhaps not quite the right place to raise this protest, but why is it that no British publishing house protest, but why ise us an English medical dictionary? will undertake to give us an excellent ones of which America is supplied wiew is one of the best examples. the book under review a long way towards meeting The compiler instances have given the alternative English spelling, but why hritish reader, for words beginning hoematohave to see those beginning hemato- . It makes it an have to see those beginning in the Empire, outside uritain, to maintain correct English spelling in their journals.

It three years since the last edition appeared. It is an alarming thought that it has been necessary to is an alarming of 3,000 new words, and that as a result anty pages. the text has had to be been brought into use and However, the words have them up when we meet them we must be able to look them up whe space has been for the first time. A little saving of space has been made by contracting the

'To be of permanent value a medicanary To be of permantent literature and this calls for frequent must cover modern literature and believes that in this and constant revision. The editor believes that illustrated new and enlaiged edition the American Illustrated Medical Dictionary will continue to prove quite sure that to practitioners and students.

A GIDE TO ANATOMY: FOR STUDENTS OF GUIDE TO ANATTICS, MASSAGE AND MEDIMEDICAL GYMNAST CAL ELECTRICITY. K. Lewis and Company, Edition. 1938. H. K. xii plus 342, with 102 illusLimited, London. 39 plates. Price, 12s. 6d.

THIs little volume is intended to serve the needs of students of medical gymnastics and massage, and as such is a guide to anatomy in a restricted divisions, The book consists essentially of two broad dructures e.g. (a) osteology (section i); (b) soft structures (sections ii, iii, iv and v) with an introductory section before each division giving, in a brief outline, the fundamentals of the nature of structure

in the following chapter or chapters. view the needs

The author has constantly kept in view the needs of his special class of students and consequently lonstress upon those structures which areatment. The cerned with this special mode of treatment. The subject-matter has accordingly been arranged in order of importance, viz, bon

then nerves and vessels.

In this brief account, every part of human terminology has been included but unfortunately old terminology has been used. One would wish thated, not only for nerves were more elaborately illustrated, subsequent the purpose of examinations but also for subsequent professional utility. Thus, muscies of the foot are important for examinations, as will be seen from the questions in the appendix, and also the sole of masseurs but no diagrams of the muscles of the of the the foot are given. Similarly, a diagram of the neurone would enable the students to understand the constitution of the nerve better than its very would description. Some of the figures in half tone would be better understood, if replaced by simple line drawings, e.g., figure 39, depicting the back muscles. The value of the book as a guide, would have been enhanced further, by a more careful selection of structures for illustrations. Some of the sketches of structures for anatomy and nerve plexuses might be replaced, without affecting the purpose of the book more appropriate diagrams of structu

directly concerned with massage. 